\title{
Foliar Chemical Protection Against Pantoea ananatis in Onion Is Negated by Thrips Feeding
}

\author{
Spencer Stumpf, ${ }^{1}$ Leana Leach, ${ }^{1}$ Rajagopalbabu Srinivasan, ${ }^{2}$ Timothy Coolong, ${ }^{3}$ Ron Gitaitis, ${ }^{1}$ and Bhabesh Dutta ${ }^{1, \dagger}$ \\ ${ }^{1}$ Department of Plant Pathology, Coastal Plain Experiment Station, University of Georgia, Tifton, GA 31793 \\ 2 Department of Entomology, University of Georgia, Griffin, GA 30223 \\ ${ }^{3}$ Department of Horticulture, University of Georgia, Athens, GA 30602 \\ Accepted for publication 1 August 2020.
}

\begin{abstract}
Center rot of onion, caused by Pantoea ananatis, is an economically important disease in onion production in Georgia and elsewhere in the United States. Growers rely on frequent foliar applications of bactericides and, in some cases, plant defense inducers to manage this disease. However, regular prophylactic application of these chemicals is not costeffective and may not be environmentally friendly. Thrips (Thrips tabaci and Frankliniella fusca) are vectors of $P$. ananatis, and their feeding may compromise the effectiveness of foliar applications against $P$. ananatis. In this study, foliar treatments with acibenzolar- $S$-methyl (Actigard 50WG), cupric hydroxide (Kocide 3000), and Actigard plus Kocide were evaluated for their effectiveness in the presence and absence of thrips infestation at two critical onion growth stages: bulb initiation and bulb swelling. Onion growth stage had no impact on the effectiveness of either Kocide or Actigard. In the absence of thrips, Kocide application resulted in reduced center rot incidence compared with Actigard, regardless of the
\end{abstract}

ABSTRACT

Center rot of onion is caused by the gram-negative bacterium Pantoea ananatis. Other Pantoea species such as P. agglomerans, $P$. allii, and $P$. stewartii subsp. indologenes have also been associated with center rot (Brady et al. 2011; Edens et al. 2006; Stumpf et al. 2018). P. ananatis can cause significant economic damage and, in severe cases, up to $100 \%$ yield loss (Goszczynska et al. 2006; Walcott et al. 2002). Characteristic symptoms of center rot include water-soaked lesions running along the length of the leaf that may gradually wilt, turn necrotic, and leave a bleached appearance (Dutta et al. 2014; Gitaitis and Gay 1997). Initial infections commonly occur on the younger leaves at the center of the plant (Nischwitz et al. 2007). After infection, the pathogen may colonize the foliage and progress into the onion bulb (Carr et al. 2013; Gitaitis and Gay 1997). Infected bulb scales are prone to secondary infections by microbes that can result in further rot and production of a foul odor. Mechanical harvest of infected onions can result in foliage breaking from the necks and bulbs left in the ground (Gitaitis 2014; Nischwitz et al. 2007).

To reduce economic losses caused by center rot of onion, an integrated pest management strategy that limits sources of initial inoculum and spread is necessary. It is important to produce and use

†Corresponding author: B. Dutta; bhabesh@uga.edu

Funding: This work was partially supported by Georgia Department of Agriculture Specialty Crop Block Grant award AWD00009682 and USDA-NIFA-ORG award 2019-51106-30191. The University of Georgia is an equal opportunity provider and employer.

*The $\boldsymbol{e}$-Xtra logo stands for "electronic extra" and indicates that one supplementary figure and one supplementary file are published online.

The author(s) declare no conflict of interest.

(c) 2021 The American Phytopathological Society growth stage. However, when thrips were present, the efficacy of both Kocide and Actigard was reduced, with bulb incidence not significantly different from the nontreated control. In independent greenhouse studies in the presence or absence of thrips, it was observed that use of protective chemicals (Kocide, Actigard, and their combinations) at different rates also affected pathogen progression into internal neck tissue and incidence of bulb rot. These results suggest that thrips infestation can reduce the efficacy of protective chemical treatments against $P$. ananatis. Thrips feeding on onion foliage and resulting feeding scars could facilitate $P$. ananatis entry and subsequently compromise the efficacy of protective chemical treatments. Therefore, an effective center rot management strategy should likely include thrips management in addition to bactericides at susceptible growth stages of onion.

Keywords: bacteriology, disease control, pest management pathogen-free seed because $P$. ananatis can be seedborne (Walcott et al. 2002). Additionally, researchers isolated epiphytic populations of pathogenic $P$. ananatis strains from more than 20 weed species commonly found near onion production fields in Georgia (Gitaitis et al. 2002). Weeds serving as a resident host for epiphytic populations of $P$. ananatis most likely serve as a local source of inoculum for center rot outbreaks (Gitaitis et al. 2002). Dutta et al. (2017) observed that $P$. ananatis survived as an epiphyte on Florida pusley (Richardia scabra L.) under different temperature and moisture conditions that mimicked environmental conditions common for the months of March, April, and May (bulb maturation) in the Vidalia onion region of Georgia. Two known insect vectors, tobacco thrips (Frankliniella fusca) and onion thrips (Thrips tabaci), have been identified as vectors of $P$. ananatis (Dutta et al. 2014, 2016; Gitaitis et al. 2003). Furthermore, the studies found that the bacterium was transmitted passively into foliar wounds via contaminated thrip feces, which resulted in foliar infection (Dutta et al. 2014, 2016). These vectors are abundant in the Vidalia onion growing counties in Georgia with $F$. fusca as the dominant species, averaging $78 \%$ of the onion-feeding adult thrips population (Riley et al. 2014).

Managing center rot is a challenge because three sources of inocula (seeds, weeds, and thrips) may contribute to disease onset and further spread of the pathogen. Cultural practices such as implementing drip irrigation to minimize pathogen dispersal through water splashing and the use of mulch to repel insect vectors have been evaluated (Gitaitis et al. 2004). These practices were of little benefit under Georgia growing conditions (Gitaitis et al. 2004). Although some commercial cultivars displayed reduced incidence to center rot infection under greenhouse and field conditions, complete resistance has not been identified (Boyhan et al. 2014; Stumpf et al. 2017). Copper-based compounds may reduce center rot incidence and severity; however, the disease 
is not effectively managed when environmental conditions are optimal for its development. Furthermore, efficacy can be hampered by the development of copper-tolerant bacterial strains (Nischwitz et al. 2007).

Acibenzolar-S-methyl (Actigard 50WG; Syngenta Crop Protection, Greensboro, NC), an analog of salicylic acid (SA), induces systemic acquired resistance (SAR) in hosts to inhibit the severity of diseases caused by bacterial and fungal pathogens (Babu et al. 2003; Cole 1999). Combinations of Actigard and copper bactericides have been used to manage bacterial diseases on vegetables under field conditions. Previous research investigated the efficacy of Actigard and copper bactericide spray programs in reducing the severity of bacterial blight of onion (caused by Xanthomonas axonopodis pv. allii) in Colorado (Gent and Schwartz 2005). Researchers found that applications of Actigard reduced epiphytic populations of $X$. axonopodis pv. allii on onion as effectively as a copper bactericide amended with an ethylenebisdithiocarbamate (EBDC) fungicide in growth chamber studies. In a multilocation field study, Actigard was as effective as copper mixed with an EBDC fungicide against $X$. axonopodis pv. allii at reducing the relative area under the disease progress curve without affecting onion bulb yield or grade (Gent and Schwartz 2005). However, the performance of Actigard and copper bactericides against $P$. ananatis on onion in Georgia has been variable with limited to no efficacy (Dutta, unpublished data).

We investigated the effect of onion growth stage on center rot incidence in bulbs. We identified three susceptible growth stages (first leaf senescence, bulb initiation, and bulb swelling) of onion where foliar infection often results in center rot incidence in the bulb (Stumpf et al. 2017). Based on these observations, we hypothesized that targeted protection specifically during these susceptible growth stages can influence center rot bulb incidence. The targeted protection was investigated using Actigard and cupric hydroxide (Kocide 3000, hereafter referred to as Kocide; DuPont, Wilmington, DE). We also hypothesized that thrips can negate these protection strategies, as disease is most severe when thrips feed during early bulbing stages (Orloff et al. 2016). This study investigated the application of targeted protective foliar sprays at bulb initiation and bulb swelling stages for improved disease management. Furthermore, we evaluated whether different rates of protective chemicals (Kocide, Actigard, and their combinations) affected pathogen colonization and bulb rot incidence in the presence or absence of thrips under greenhouse conditions.

\section{MATERIALS AND METHODS}

Bacterial strain, inoculum preparation, and copper sensitivity. P. ananatis strain PNA 97-1 (accession DQ777968), isolated in 1997 from the foliage of center rot-infected onion plants in Toombs County, Georgia, was used in this study. For inoculum preparation, a single colony from a 48 -h-old culture was used to inoculate $25 \mathrm{ml}$ of nutrient broth, which was shaken on a rotary shaker (Inova; New Brunswick Scientific, Edison, NJ) at $160 \mathrm{rpm}$. After $12 \mathrm{~h}$ of incubation, the bacterial suspension was centrifuged at $10,000 \times g$ (Allegra 25R; Beckman Coulter, Fullerton, CA) for $1 \mathrm{~min}$. The supernatant was discarded, the pellet was resuspended in $0.1 \mathrm{M}$ of phosphate-buffered saline (PBS), and the inoculum was adjusted photometrically using a spectrophotometer (Spectronic 20; Bausch and Lomb, Rochester, NY) to an optical density of 0.3 at $600 \mathrm{~nm}$ (approximately $1 \times 10^{8} \mathrm{CFU} / \mathrm{ml}$ ). The final inoculum concentration was obtained by serial dilution in PBS to approximately $1 \times 10^{6} \mathrm{CFU} / \mathrm{ml}$. Prior to this study, the copper tolerance status of PNA 97-1 was checked in $\mathrm{CuSO}_{4} 0 \cdot 5 \mathrm{H}_{2} \mathrm{O}$-amended nutrient agar (NA) plates. To determine the copper tolerance, the bacterial strain was grown on nutrient broth overnight and resuspended to an optical density of 0.3 at $600 \mathrm{~nm}\left(1 \times 10^{8} \mathrm{CFU} /\right.$ $\mathrm{ml})$ as previously described, and suspensions were serially diluted to a concentration of $1 \times 10^{6} \mathrm{CFU} / \mathrm{ml}$. Later, aliquots of $50 \mu \mathrm{l}$ were spread onto NA and NA plates amended with 200 ppm of
$\mathrm{CuSO}_{4} 0 \cdot 5 \mathrm{H}_{2} \mathrm{O}$. Plates were incubated at $28^{\circ} \mathrm{C}$ for 48 to $72 \mathrm{~h}$ and observed for bacterial growth.

$F$. fusca maintenance. A colony of $F$. fusca was established in 2009 on noninfected peanut leaflets of the cultivar Georgia Green with thrips collected from peanut blooms from the Belflower Farm at the University of Georgia Tifton Campus. Since then, thrips have been maintained in Munger cages (Munger 1942) on peanut (cultivar Georgia Green) leaflets. Munger cages were maintained in a growth chamber (Thermo Scientific, Dubuque, IA) at 25 to $30^{\circ} \mathrm{C}$ with a 14-h/10-h light/dark photoperiod. To confirm whether the peanut plants were negative for $P$. ananatis, leaflets $(n=5)$ without surface sterilization were rinsed in $2 \mathrm{ml}$ of $0.1 \mathrm{M}$ PBS for $2 \mathrm{~min}$. Aliquots of $0.1 \mathrm{ml}$ were then spread plated on PA-20 semi-selective medium (Goszczynska et al. 2006) and incubated. Thrips in the colony were also crushed and spread plated on PA-20 medium to check for $P$. ananatis contamination. The majority of individuals in the colonies $(>80 \%)$ were female. Adult females of relatively the same age were subsequently used for all experiments.

Effect of targeted growth stage chemical applications to mitigate center rot incidence in bulbs. Onion seedlings (cultivar Century) were established in $10 \times 8$-cm (diameter $\times$ height) plastic pots (Hummert International, Earth City, MO) containing a commercial potting mix (Scotts Miracle-Gro Company, Marysville, $\mathrm{OH})$. The seedlings were maintained in greenhouse conditions at 24 to $27^{\circ} \mathrm{C}$ and 70 to $80 \% \mathrm{RH}$ with ambient light from December to May. Potted plants were kept on metal benches $1 \mathrm{~m}$ off the ground and watered at the base of the stem every other day by hand. Plants reached a height of 25 to $30 \mathrm{~cm}$ with five to six leaves at the bulb initiation stage and six to eight leaves at the bulb swelling stage. We also evaluated the temporal expression of pathogenesis-related protein $P R 1$ and $P R 5$ genes in onion seedlings upon Actigard foliar application under greenhouse conditions (Supplementary File S1).

Foliar treatments with Actigard, Kocide, or Actigard plus Kocide were applied at either the bulb initiation or bulb swelling growth stage. Kocide was mixed with water at a rate of $1.7 \mathrm{~kg} / \mathrm{ha}$ and Actigard was mixed with water at a rate of $35 \mathrm{~g} / \mathrm{ha}$. The sequence of treatments started with Actigard, which was applied $48 \mathrm{~h}$ prior to inoculation (based on the gene expression studies; Supplementary Fig. 1), whereas Kocide was applied $24 \mathrm{~h}$ prior to inoculation. The treatment that comprised of Actigard and Kocide also followed a similar sequence. Foliar chemical treatments were applied to foliage until runoff using a sterile backpack sprayer. Plants were inoculated with $P$. ananatis (PNA 97-1; $10^{6} \mathrm{CFU} / \mathrm{ml}$ ) at $48 \mathrm{~h}$ after Actigard application or $24 \mathrm{~h}$ after Kocide application. Plants were spray inoculated with a bacterial suspension until runoff as described above. Plants not treated with chemicals but sprayed with sterile water served as the nontreated noninoculated control (negative control), whereas plants not treated but inoculated with PNA 97-1 served as the nontreated inoculated control.

Twenty-four hours after inoculum was applied, onion seedlings were placed in a $47.5 \times 47.5 \times 93-\mathrm{cm}$ insect rearing cage (BugDorm, Taiwan) and $30 P$. ananatis-free $F$. fusca adults were released. Overall, 10 insect cages were used for each treatment and each insect cage contained 10 seedlings per treatment. Onion seedlings $(n=10$ per insect cage per treatment per experiment) without thrips were also placed inside an insect cage. Insect cages were arranged in a randomized complete block design inside a greenhouse and each treatment was replicated 10 times. Three independent experiments were conducted. Onions were watered as necessary at the base of the plant until maturity.

When foliar necks were soft, indicating maturity, bulbs were harvested, stored temporarily in sterile $4.5-\mathrm{kg}$ mesh onion bags (Harris Seeds, Rochester, NY), and transported to the Coastal Plain Experiment Station (CPES) Natural Products Laboratory (University of Georgia, Tifton, GA). Onion bulbs were graded for any visual symptoms prior to curing. Bulbs displaying extreme and suspicious softening of the neck were cut longitudinally and assessed for center rot symptoms. Bulbs that appeared healthy were cured at room temperature $\left(25^{\circ} \mathrm{C}\right)$ for 7 days. After 7 days of curing, bulbs were cut 
through the center using a sterile knife and assessed for center rot symptoms (discoloration of interior bulb scales). Onion bulbs displaying center rot symptoms were recorded as diseased, and asymptomatic bulbs were recorded as healthy. Bulb incidence of center rot was calculated for each chemical treatment at two growth stages by adding the number of bulbs discarded prior to curing and the number of bulbs displaying symptoms after curing divided by the total number of bulbs assessed $\times 100$. Mean bulb incidences of center rot with chemical treatments at two onion growth stages with and without thrips exposure were analyzed using Proc Glimmix with Beta distribution for percentage response variables in SAS 9.4 software (SAS Institute, Cary, NC) at the $P=0.05$ level. The interactive effects of chemical application $\times$ growth stage and chemical application $\times$ thrips exposure on center rot incidence in onion bulbs were also analyzed.

Effect of protective chemical application on colonization of onions and thrips by $P$. ananatis and center rot bulb incidence. There were no significant differences between initiating the application of chemicals at the bulb initiation and bulb swelling stages. Therefore, greenhouse experiments were designed to further evaluate the protective chemicals (at different rates) and their combinations at only the bulb initiation stage. Further detailed pathogen population colonization, thrips infestation status, and expression of $P R I$ and $P R 5$ were also evaluated.

Onion seedlings (cultivar Century) were established and maintained in greenhouse conditions as described above. At the bulb initiation stage, onion seedlings were treated with three rates of Actigard, two rates of Kocide, or combinations of Actigard and Kocide (Table 1). The sequence of treatments started with Actigard, which was applied $48 \mathrm{~h}$ prior to inoculation, whereas Kocide was applied $24 \mathrm{~h}$ prior to inoculation. The treatment that comprised Actigard and Kocide also followed a similar sequence. Actigard was applied $24 \mathrm{~h}$ prior to Kocide applications and inoculations with P. ananatis were made $48 \mathrm{~h}$ after Actigard application $(24 \mathrm{~h}$ after Kocide application). Three different rates of Actigard (35, 52.5, or $70 \mathrm{~g} / \mathrm{ha}$ ) were mixed in water (5 liters) and applied using a backpack sprayer. Two rates of Kocide (1.7 or $2.2 \mathrm{~kg} / \mathrm{ha}$ ) were applied in a similar manner $24 \mathrm{~h}$ after Actigard treatment. Treatments that included a combination of three rates of Actigard and two rates of Kocide also followed a similar scheme. Mixed combinations were as follows: $35 \mathrm{~g} / \mathrm{ha}$ of Actigard plus $1.7 \mathrm{~kg} / \mathrm{ha}$ of Kocide, $35 \mathrm{~g} / \mathrm{ha}$ of Actigard plus $2.2 \mathrm{~kg} / \mathrm{ha}$ of Kocide, $52.5 \mathrm{~g} / \mathrm{ha}$ of Actigard plus $1.7 \mathrm{~kg} /$ ha of Kocide, $52.5 \mathrm{~g} / \mathrm{ha}$ of Actigard plus $2.2 \mathrm{~kg} / \mathrm{ha}$ of Kocide, $70 \mathrm{~g} / \mathrm{ha}$ of Actigard plus $1.7 \mathrm{~kg} / \mathrm{ha}$ of Kocide, and $70 \mathrm{~g} / \mathrm{ha}$ of Actigard plus $2.2 \mathrm{~kg} / \mathrm{ha}$ of Kocide. Plants were inoculated with $P$. ananatis (PNA $\left.97-1 ; 1 \times 10^{6} \mathrm{CFU} / \mathrm{ml}\right)$ at $48 \mathrm{~h}$ after Actigard treatment or $24 \mathrm{~h}$ after Kocide treatment. Onion plants treated in a similar manner (three rates of Actigard, two rates of Kocide, or their combinations) at the bulb initiation stage were exposed to thrips. Twenty-four hours after $P$. ananatis inoculation, treated onion seedlings $(n=30$ per treatment per experiment) were placed in a cylindrical Mylar film cage with a copper mesh (approximately $200 \mu \mathrm{m}$; Grafix Plastics, Cleveland, $\mathrm{OH}$ ). After seedlings were placed in individual Mylar cages, $P$. ananatis-free $F$. fusca adults $(n=30)$ were released per cage. Onion seedlings ( $n=30$ per treatment per experiment) without thrips were also placed inside a Mylar film cage. $F$. fusca adult females of relatively the same age were used for all experiments. Onion seedlings in a pot served as a single experimental unit. Onion seedlings were maintained until harvest maturity. Seedlings in Mylar film cages were placed in a randomized complete block design inside a greenhouse and each treatment was replicated 30 times. Two independent experiments were conducted. Onions were watered as necessary at the base of the plant until maturity. Plants sprayed with sterile water and inoculated with $P$. ananatis served as a nontreated inoculated control. Noninoculated and sterile watertreated plants served as a nontreated noninoculated control (negative control). Control plants were either exposed to thrips under the insect cage or left nonexposed.

Temporal dynamics of $\mathrm{P}$. ananatis populations in internal neck tissues of onion. Population dynamics of $P$. ananatis for each treatment with and without thrips exposure were determined from the internal neck tissues of onion bulbs. At each sampling period $(0$, $7,14,21,28,35$, and 40 days postinoculation [dpi]), three onion bulbs were sampled to determine bacterial populations from the internal neck tissue. To achieve this, tunic layers from sampled onion bulbs were removed and surface disinfested with $70 \%$ ethanol; the surface was then wiped with sterile water using a sterile paper towel as described previously (Dutta et al. 2014). Internal neck tissue ( $1 \mathrm{~cm}$ above the shoulder of the bulb) was excised using a sterile scalpel, weighed, and used for $P$. ananatis enumeration. For

TABLE 1. Percentage of bulb incidence and relative expression of pathogenesis-related protein genes $P R 1$ and $P R 5$ in onion seedlings in response to chemical treatment with and without thrips exposure

\begin{tabular}{|c|c|c|c|c|c|c|}
\hline \multirow[b]{2}{*}{$\begin{array}{l}\text { Treatments and rate } \\
\text { (listed per acre) }\end{array}$} & \multicolumn{2}{|c|}{ Bulb incidence $(\%)^{\mathrm{x}}$} & \multicolumn{2}{|c|}{ Relative expression of $P R I^{y}$} & \multicolumn{2}{|c|}{ Relative expression of $P R 5$} \\
\hline & $\begin{array}{l}\text { Thrips } \\
\text { exposure }\end{array}$ & $\begin{array}{l}\text { Without thrips } \\
\text { exposure }\end{array}$ & $\begin{array}{l}\text { Thrips } \\
\text { exposure }\end{array}$ & $\begin{array}{l}\text { Without thrips } \\
\text { exposure }\end{array}$ & $\begin{array}{l}\text { Thrips } \\
\text { exposure }\end{array}$ & $\begin{array}{l}\text { Without thrips } \\
\text { exposure }\end{array}$ \\
\hline \multicolumn{7}{|l|}{ Actigard (g/ha) } \\
\hline 52.5 & $82.4 \mathrm{Aa}$ & $71.2 \mathrm{Aa}$ & $3.8 \mathrm{Aa}$ & $3.7 \mathrm{Aa}$ & $3.8 \mathrm{Aa}$ & $2.8 \mathrm{Aa}$ \\
\hline 70 & $72.2 \mathrm{Aa}$ & $65.8 \mathrm{Aa}$ & $3.6 \mathrm{Aa}$ & 4.1 Aa & $4.2 \mathrm{Aa}$ & $3.6 \mathrm{Aa}$ \\
\hline \multicolumn{7}{|l|}{ Kocide 3000 (kg/ha) } \\
\hline \multicolumn{7}{|c|}{$\begin{array}{l}\text { Actigard (g/ha) + Kocide } 3000 \\
(\mathrm{~kg} / \mathrm{ha})\end{array}$} \\
\hline $35+1.7$ & $78.4 \mathrm{Aa}$ & $38.4 \mathrm{Bb}$ & $2.9 \mathrm{Aa}$ & $2.5 \mathrm{Aa}$ & $3.6 \mathrm{Aa}$ & $4.1 \mathrm{Aa}$ \\
\hline $35+2.2$ & $83.8 \mathrm{Aa}$ & $29.2 \mathrm{Bb}$ & 4.2 Aa & $3.8 \mathrm{Aa}$ & $3.8 \mathrm{Aa}$ & $2.7 \mathrm{Aa}$ \\
\hline $52.5+1.7$ & $82.6 \mathrm{Aa}$ & $36.4 \mathrm{Bb}$ & $3.8 \mathrm{Aa}$ & 4.2 Aa & $4.7 \mathrm{Aa}$ & $4.8 \mathrm{Aa}$ \\
\hline $52.5+2.2$ & $75.4 \mathrm{Aa}$ & $37.6 \mathrm{Bb}$ & $3.6 \mathrm{Aa}$ & $3.8 \mathrm{Aa}$ & $4.2 \mathrm{Aa}$ & $3.2 \mathrm{Aa}$ \\
\hline $70+1.7$ & $72.8 \mathrm{Aa}$ & $39.6 \mathrm{Bb}$ & $3.2 \mathrm{Aa}$ & $2.9 \mathrm{Aa}$ & 4.8 Aa & $2.6 \mathrm{Aa}$ \\
\hline
\end{tabular}

$\mathrm{x}$ Percentage of bulb incidence was calculated based on the number of bulbs displaying center rot symptoms (number of bulbs with center rot prior to curing + number of bulbs with center rot after 1 week of curing) divided by the total number of bulbs evaluated $\times 100$.

${ }^{y}$ Mean relative expression of $P R 1$ and $P R 5$ in onion seedlings treated with acibenzolar- $S$-methyl (Actigard 50WG), copper hydroxide (Kocide 3000), or both at different rates under greenhouse conditions. Relative expressions of $P R 1$ and $P R 5$ were determined in onion foliar tissues collected $72 \mathrm{~h}$ postapplication. Leaf tissue samples from three replicates per treatment were collected for gene expression analysis and a total of two independent experiments were conducted.

${ }^{\mathrm{z}}$ Means within the same treatment class followed by different uppercase (column-wise comparison in each section) and lowercase (row-wise comparison in each section) letters are significantly different at $P<0.05$ according to Fisher's least significant difference test. 
enumeration, tissue samples were placed individually in $1 \mathrm{ml}$ of 0.1 M PBS in 2-ml microcentrifuge tubes, macerated using a sterile glass rod, and vigorously agitated for $30 \mathrm{~s}$ (Vortex Genie2; Fisher Scientific International). The tissue macerates were 10-fold serially diluted in $1 \mathrm{ml}$ of PBS. Subsequently, 100- $\mu$ l aliquants were spread plated onto semi-selective PA-20 and incubated for 5 to 7 days at $28^{\circ} \mathrm{C}$. After incubation, bacterial colonies were enumerated and recorded from each sampling point. Area under the growth progress curve (AUGPC) for each replicate per treatment was calculated as follows:

$$
\Sigma_{i=1}\left[\left(Y_{i+n 1}+Y_{i}\right)\right] / 2\left[X_{i+1}-X_{i}\right]
$$

where $Y_{i}$ is the bacterial population at the $i$ th observation, $X_{i}$ is the time in hours at the $i$ th observation, and $n$ is the total number of observations. Analysis of variance was conducted on the AUGPC values to determine treatment effects on $P$. ananatis populations, and Fisher's least significant difference (LSD) test $(P<0.05)$ was used for mean separations. The same treatments were compared under thrips exposure and without thrips exposure scenarios with the $t$ test.

Determination of the percentage of thrips carrying internal populations of $\mathrm{P}$. ananatis. Percentages of thrips that internally harbored $P$. ananatis were determined for each treatment that was exposed to thrips as described above. Using a fine-tip paintbrush, four individual adult $F$. fusca were randomly sampled from the whorl of each plant inside the Mylar cage at 0,7, 14, and 21 dpi. Thrips sampling for $P$. ananatis was conducted for the two independent greenhouse trials described above. The sampled thrips were placed individually into separate $1.5-\mathrm{ml}$ microcentrifuge tubes and surface sterilized as described previously (Dutta et al. 2014). After surface sterilization, the collected thrips (adult) from each seedling per treatment were macerated individually using a plastic pestle (Polypropylene Pellet Pestle; Grainger Inc., Jacksonville, FL) and the tissue macerates were plated onto PA-20 medium. Individual thrips were assayed for the presence of internal $P$. ananatis. To ensure that $P$. ananatis was absent after the last rinsing step, the surface sterilization rinsate (from last rinsing step with PBS) was also tested for the presence of $P$. ananatis by plating as described above. Mean percentages of thrips harboring internal $P$. ananatis populations were statistically analyzed with repeated-measures analysis $(P<0.05)$ using Proc Glimmix in SAS 9.4 software.

Expression of SA-induced genes (PR1 and $\mathrm{PR} 5)$ in response to chemical treatment under thrips versus nonthrips exposure. Relative expressions of $P R 1$ and $P R 5$ were determined in onion foliar tissues collected at $48 \mathrm{~h}$ after thrips exposure $(72 \mathrm{~h}$ after $P$. ananatis inoculation). Three seedlings from each treatment were sampled and a total of two independent experiments were conducted. Leaf samples were immediately stored in liquid nitrogen and later transferred to a $-80^{\circ} \mathrm{C}$ freezer at CPES until needed for further analysis. Leaves were ground in liquid nitrogen and total RNA was extracted from $50 \mathrm{mg}$ of ground leaf tissue using the manufacturer's protocol (RNeasy Plant Mini Kit). First-strand cDNA was synthesized from $500 \mathrm{ng}$ of total RNA by reverse transcription using the iScript cDNA synthesis kit (Bio-Rad Laboratories Inc., Hercules, CA). Then quantitative PCR was conducted on a Smart Cycler System (Cepheid, Sunnyvale, CA) using iQ SYBR Green Supermix (Bio-Rad) and specific primer pairs for PRI and PR5 as described previously by ElMorsi et al. (2015) with a minor modification in annealing temperatures of 59 and $56^{\circ} \mathrm{C}$, respectively. The beta-actin gene was used as a control and was assessed using the primer pair described by ElMorsi et al. (2015). The cycle threshold (Ct) values thus obtained were converted into relative fold differences of marker genes in treated samples compared with the water control samples (negative control) and relative to the endogenous control gene using the $2^{-\Delta \Delta \mathrm{Ct}}$ method (Livak and Schmittgen 2001; Schmittgen and Livak 2008). This was done after we verified the stability of the endogenous control genes and that the primer pairs had high, comparable PCR efficiencies (Schmittgen and Livak 2008).
Relative fold changes of target genes were calculated and compared. The effect of chemical application and thrips exposure treatment combinations on the relative expression of $P R 1$ and $P R 5$ was determined and compared by Fisher's LSD at $P=0.05$.

Bulb incidence of center rot. At harvest maturity, bulbs were harvested for each treatment (thrips exposed and nonexposed), stored temporarily in surface-disinfested $4.5-\mathrm{kg}$ mesh onion bags (Harris Seeds), and transported to the CPES Natural Products Laboratory. Harvested bulbs were stored at room temperature $\left(25^{\circ} \mathrm{C}\right)$ for 7 days without prior grading. After 7 days of curing, bulbs were cut through the center using a sterile knife and assessed for center rot symptoms (discoloration of interior bulb scales). Onions displaying center rot symptoms were recorded as diseased and asymptomatic bulbs were recorded as healthy. Center rot bulb incidence was calculated for each chemical treatment with and without thrips exposure as the number of symptomatic bulbs divided by the total number of stored bulbs $\times 100$. Mean incidences of center rot for each chemical treatment (thrips exposed versus nonexposed) were calculated using Proc Glimmix with Beta distribution for percentage response variables in SAS 9.4 (SAS Institute). The effects of chemical application and thrips exposure combination on center rot incidence in onion bulbs were also analyzed as described above. The effect of the interaction of chemical treatment and thrips exposure was analyzed using Proc Glimmix in SAS 9.4.

Bacterial identification. To confirm that symptoms observed were caused by $P$. ananatis, bacteria from symptomatic bulbs $(n=$ 10) were isolated from margins of necrotic tissue, streaked onto Tryptic soy broth agar plates, and incubated for $48 \mathrm{~h}$ at $28^{\circ} \mathrm{C}$. After $48 \mathrm{~h}$ of incubation, yellow-pigmented colonies were isolated and tested for $P$. ananatis using species-specific TaqMan-based PCR assays as described by Stumpf et al. (2017). The above tests were also utilized for bulbs whose foliage was treated with $0.1 \mathrm{M}$ of PBS but not inoculated with $P$. ananatis.

\section{RESULTS}

Bacterial strain, inoculum preparation, and copper sensitivity. $P$. ananatis (PNA 97-1) did not grow on NA media amended with $200 \mathrm{ppm}$ of $\mathrm{CuSO}_{4} \cdot 5 \mathrm{H}_{2} \mathrm{O}$. However, confluent colony growth was observed on nonamended NA plates.

F. fusca maintenance. $P$. ananatis colonies were not recovered from the $F$. fusca individuals on PA-20 medium, indicating that thrips were free of $P$. ananatis. These results indicate that $P$. ananatis was not acquired by $F$. fusca and therefore was not spread within or between onion plants through stercorarian transmission (transmission through feces).

Effect of targeted growth stage chemical applications to mitigate center rot incidence in bulbs. The effects of protective foliar chemical treatments $(1.7 \mathrm{~kg} / \mathrm{ha}$ of Kocide, $35 \mathrm{~g} /$ ha of Actigard, or $1.7 \mathrm{~kg} / \mathrm{ha}$ of Kocide plus $35 \mathrm{~g} / \mathrm{ha}$ of Actigard) at two growth stages (bulb initiation or bulb swelling) on reducing center rot bulb incidence were evaluated for two scenarios: either exposure to thrips or not. There were no significant interactions among chemical foliar treatments at different growth stages and chemical treatments with thrips infestation $(P=0.721)$. However, main effects of chemical treatment $(P<0.034)$ and thrips infestation $(P<0.001)$ significantly affected center rot incidence in bulbs. In addition, the effects of three experiments were not significant $(P=$ 0.142 ); hence, the data were pooled and analyzed.

The effect of chemical application on $P$. ananatis bulb incidence at two onion growth stages without thrips infestation was not significant $(P=0.362)$; hence, bulb incidence data at bulb initiation and bulb swelling stages were pooled. For the treatments that had no thrips exposure but were treated with chemicals at both growth stages, center rot incidence in bulbs was significantly lower than the nontreated $P$. ananatis-inoculated control (bulb incidence $=54.5 \%$; $P=0.034$ ) (Fig. 1A). The mean center rot incidence in bulbs treated with Kocide (bulb incidence $=16.5 \%$ ) and Kocide plus Actigard 
(bulb incidence $=18.2 \%$ ) was significantly lower than Actigard only (bulb incidence $=39.2 \%$ ) (Fig. 1A). Center rot symptoms were not observed on bulbs whose foliage was treated with sterile water and not inoculated with $P$. ananatis.

The effect of chemical application on $P$. ananatis bulb incidence at two onion growth stages with thrips exposure was not significant $(P=0.272)$ (data not shown); hence, data for bulb incidence at bulb initiation and bulb swelling stages were pooled. In addition, the overall effect of chemical treatment on $P$. ananatis bulb incidence in the presence of thrips was not significant $(P=0.615)$. A mean incidence of $45.2 \%$ was observed for plants treated with Kocide only, $45.6 \%$ for Kocide plus Actigard treatment, and $52.2 \%$ for Actigard-only treatment (Fig. 1B). In addition, the nontreated control (P. ananatis only) displayed a mean bulb incidence of $48.5 \%$ (Fig. 1B). Center rot symptoms were not observed for bulbs used as a negative control.

Since effects of chemical treatments upon thrips feeding were not anticipated, quantitative assessments of thrips feeding injury were not made. However, qualitative assessments of thrips foliar feeding damage at harvest were made. Irrespective of the chemical treatment applied, onion seedlings that were exposed to thrips had silvery patches or streaks on the leaves, which were likely attributable to feeding. On some foliage, tiny black "tar" spots, which were remnants of thrip excrement, were an indication of thrips feeding. Thrips feeding-associated injury was not observed in plants that were not exposed to thrips.

Effect of protective chemical application on colonization of onions and thrips by $P$. ananatis and center rot bulb incidence. Temporal dynamics of $\mathrm{P}$. ananatis populations in internal neck tissue of onion. For seedlings without thrips exposure, onion seedlings treated with only water but challenge inoculated with $P$. ananatis (in foliar tissue) resulted in a gradual increase of bacterial populations in internal neck tissues from 7 to $40 \mathrm{dpi}$. At $7 \mathrm{dpi}$, the mean $P$. ananatis population was $3.8 \times 10^{3} \mathrm{CFU} /$ $\mathrm{g}$ of neck tissue, increased to $1.2 \times 10^{6} \mathrm{CFU} / \mathrm{g}$ by $21 \mathrm{dpi}$, and reached a population of $2.6 \times 10^{8} \mathrm{CFU} / \mathrm{g}$ by $40 \mathrm{dpi}$ (Fig. 2A). Actigard applications at $35,52.5$, and $70 \mathrm{~g} /$ ha followed a similar trend of $P$. ananatis growth in internal neck tissues from 7 to $40 \mathrm{dpi}$ (Fig. 2A). At $7 \mathrm{dpi}, P$. ananatis populations for the three different Actigard rates ranged from $2.1 \times 10^{2}$ to $3.7 \times 10^{2} \mathrm{CFU} / \mathrm{g}$, which gradually increased to a final population range of $2.3 \times 10^{8}$ to $4.8 \times$ $10^{8} \mathrm{CFU} / \mathrm{g}$ by $40 \mathrm{dpi}$ (Fig. 2A). P. ananatis populations were not detected from internal neck tissues until 21 dpi for onion seedlings that were treated with either Kocide (two rates) or its combination with Actigard (six different combinations). For these treatments, P. ananatis populations ranged from $1.8 \times 10^{2}$ to $5.2 \times 10^{2} \mathrm{CFU} / \mathrm{g}$ at $21 \mathrm{dpi}$, then gradually increased to a final population range of $4.8 \times$ $10^{3}$ to $2.1 \times 10^{4} \mathrm{CFU} / \mathrm{g}$ by $40 \mathrm{dpi}$, which was four to five $\log _{10}$-orders reduced than Actigard only and the nontreated control (P. ananatis only) (Fig. 2A). AUGPC values were significantly reduced for onion seedlings that were treated with either Kocide (two rates) or its combination with Actigard (six different combinations) compared with $P$. ananatis (control) and Actigard-only treatments $(P<0.001)$ (Fig. 3). P. ananatis populations were not recovered from internal neck tissue of bulbs of the negative control.

For seedlings with thrips exposure, $P$. ananatis populations in internal neck tissues were detected as early as 7 dpi from both treated and nontreated seedlings that were exposed to thrips. Nontreated onion seedlings that were inoculated with $P$. ananatis and later exposed to thrips had a gradual increase in bacterial populations in internal neck tissues from 7 to $40 \mathrm{dpi}$. At $7 \mathrm{dpi}$, the bacterial population was $1.7 \times 10^{5} \mathrm{CFU} / \mathrm{g}$, gradually increased to $2.6 \times 10^{7} \mathrm{CFU} / \mathrm{g}$ by $21 \mathrm{dpi}$, and reached a final population of $3.4 \times$ $10^{10} \mathrm{CFU} / \mathrm{g}$ by $40 \mathrm{dpi}$ (Fig. 2B). Actigard applications at three different rates $(35,55.2$, and $70 \mathrm{~g} / \mathrm{ha})$ showed a similar trend from 7 to $40 \mathrm{dpi}$. At $7 \mathrm{dpi}$, $P$. ananatis populations for the three different Actigard rates ranged from $5.4 \times 10^{3}$ to $3.8 \times 10^{4} \mathrm{CFU} / \mathrm{g}$ and gradually increased to a final population range of $7.5 \times 10^{8}$ to $8.1 \times$ $10^{9} \mathrm{CFU} / \mathrm{g}$ by $40 \mathrm{dpi}$ (Fig. 2B). For the treatments that included Kocide (two rates) or its combination with Actigard (six different combinations), $P$. ananatis populations ranged from $5.8 \times 10^{3}$ to $1.4 \times 10^{4} \mathrm{CFU} / \mathrm{g}$ at $7 \mathrm{dpi}$, which gradually increased to a final
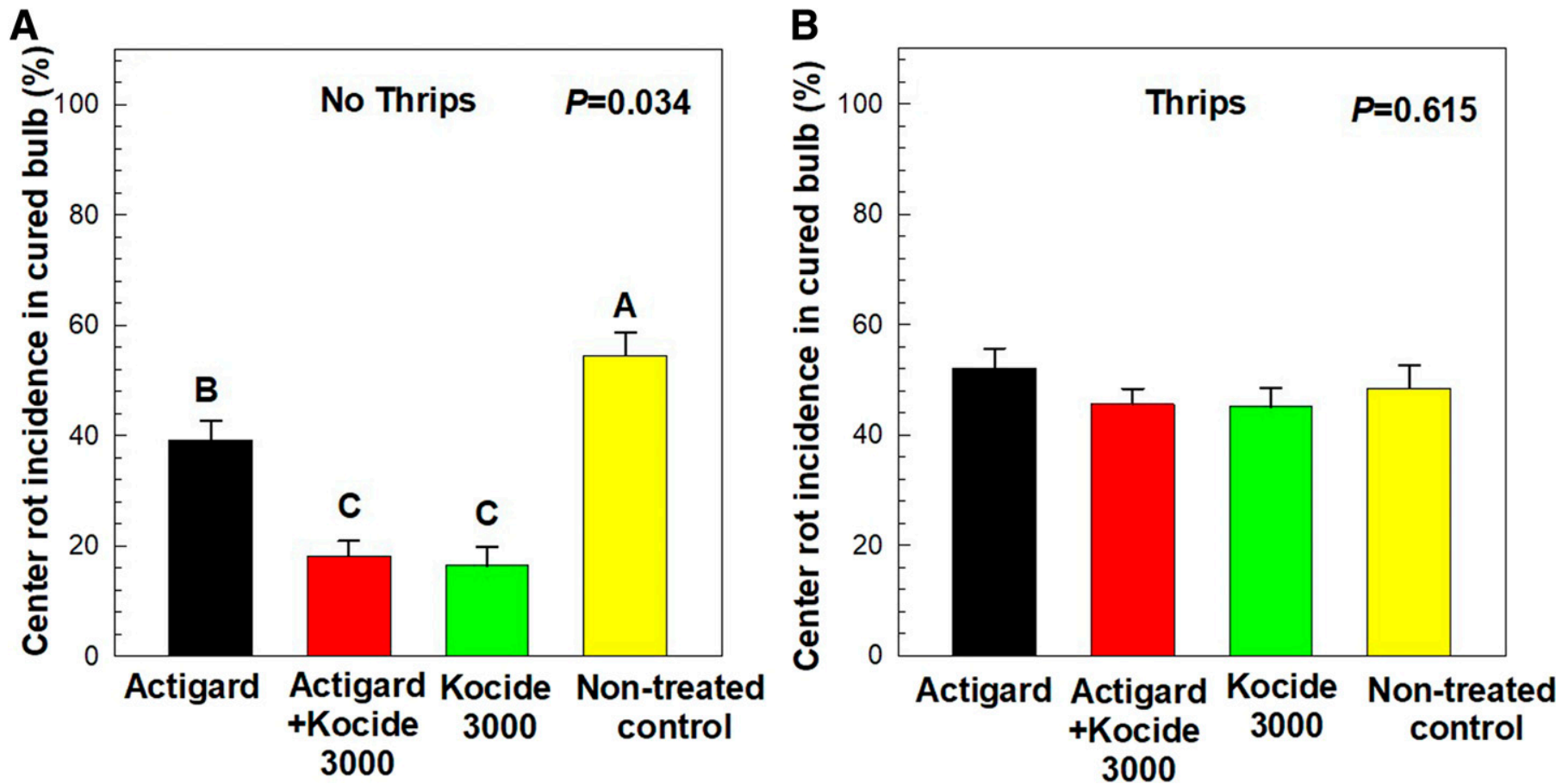

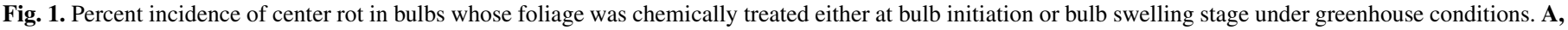

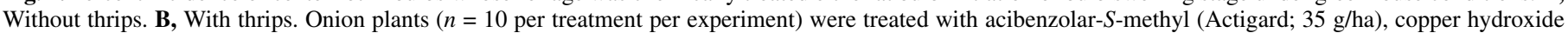

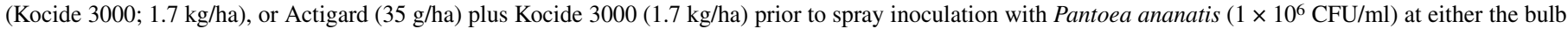

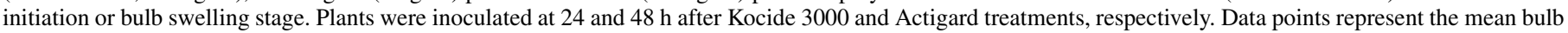

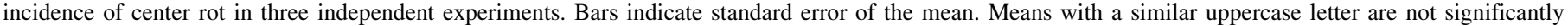
different according to Fisher's least significant difference test at $P=0.05$. 
population range of $8.2 \times 10^{8}$ to $5.8 \times 10^{9} \mathrm{CFU} / \mathrm{g}$ by $40 \mathrm{dpi}$ (Fig. $2 \mathrm{~B}$ ). The effects of chemical treatments on AUGPC values were not significant $(P=0.423)$ (Fig. 3). When effects of thrips exposure and nonthrips exposure were evaluated for the same chemical treatments, significantly higher AUGPC values $(P<0.05)$ were observed for onion seedlings exposed to thrips (Fig. 3). P. ananatis populations were not recovered from onions used as the negative control.

Determination of the percentage of thrips carrying internal populations of $\mathrm{P}$. ananatis. Thrips were sampled, surface sterilized, and assayed for the presence of internal populations of $P$. ananatis. All thrips sample rinsates from the last sterilization step were negative for $P$. ananatis on PA-20 medium. The percentage of $P$. ananatis-positive thrips did not differ significantly among treatments at 0 and $7 \mathrm{dpi}(P=0.437)$. At $7 \mathrm{dpi}$, the mean percentage of $P$. ananatis-positive thrips ranged from 46.6 to $60 \%$. By $14 \mathrm{dpi}$, the percentage of $P$. ananatis-positive thrips ranged from 73.3 to $100 \%$. By $21 \mathrm{dpi}, 100 \%$ of the sampled thrips across the treatments harbored the bacterium. The effect of treatments on the percentage of $P$. ananatis-positive thrips was not significant at $14 \mathrm{dpi}(P=$ $0.527)$ and $21 \mathrm{dpi}(P=0.382)$.

The chemical treatments did not affect thrips feeding; hence, quantitative assessments of thrips feeding injury were not made. However, qualitative assessments of onion bulbs and associated foliage at harvest were made for thrips feeding as described above. Irrespective of the chemical treatment applied, onion seedlings exposed to thrips had thrips feeding-associated injuries such as silvery patches or streaks on the leaves. Thrips feeding damage was not observed in plants not exposed to thrips.

Expression of SA-induced genes (PR1 and PR5) in response to chemical treatment under thrips versus nonthrips exposure. For seedlings without thrips exposure, the effects of chemical treatments on PRI and PR5 in plants that were not exposed to thrips were significant $(P<0.05)$. In the case of $P R 1$, expression was significantly higher for treatments with Actigard only (three rates) or its combination with Kocide (six combinations) compared with Kocide-only treatments (two rates) and the nontreated control (P. ananatis only). Relative expression ranged from 2.5 to 4.2 for Actigard only (three rates) or its combination with Kocide (six combinations), whereas expression ranged from 0.9 to 1.5 for Kocide only and the nontreated control (P. ananatis only) (Table 1). Similar trends were observed in the case of $P R 5$ expression, with significantly higher relative expression with Actigard only (three rates) or its combination with Kocide (six combinations) compared with Kocide-only treatments (two rates) and the nontreated control (P. ananatis only). Relative expression ranged from 2.9 to 4.1 for Actigard only (three rates) or its combination with Kocide (six combinations), whereas it ranged from 0.7 to 1.8 for Kocide only and the nontreated control ( $P$. ananatis only) (Table 1$)$.

For seedlings with thrips exposure, the effects of chemical treatments on $P R 1$ and $P R 5$ expression in plants exposed to thrips were significant $(P<0.05)$. In the case of $P R 1$, expression was significantly higher for onions treated with Actigard only (three rates) or its combination with Kocide (six combinations) compared with Kocide only (two rates) and the nontreated control (P. ananatis only). Relative expression ranged from 3.6 to 4.8 for Actigard only (three rates) or its combination with Kocide (six combinations), whereas expression ranged from 0.9 to 1.7 for Kocide only and the nontreated control (P. ananatis only) (Table 1).

Relative expression of $P R 5$ was significantly higher for Actigard only (three rates) or its combination with Kocide (six combinations) compared with Kocide only (two rates) and the nontreated control (P. ananatis only). Relative expression for PR5 ranged from 2.6 to 4.1 with Actigard only (three rates) or its combination with Kocide (six combinations), whereas it ranged from 0.7 to 1.6 for Kocide only and the nontreated control (P. ananatis only) (Table 1).
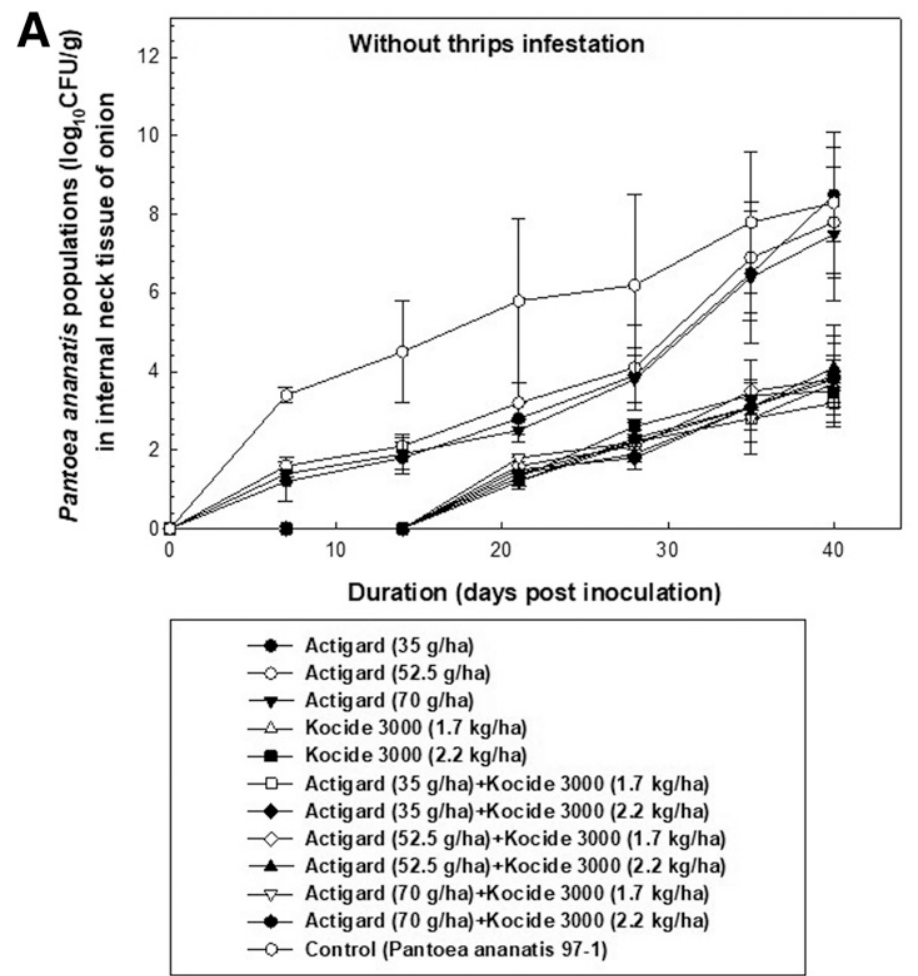

Fig. 2. Temporal dynamics of Pantoea ananatis populations ( $\log _{10} \mathrm{CFU} / \mathrm{g}$ of fresh tissue weight) in internal neck tissues of onions in response to chemical treatments (different rates) with and without thrips exposure. Population dynamics of $P$. ananatis for each treatment (acibenzolar- $S$-methyl [Actigard; three rates], copper hydroxide [Kocide 3000; two rates], and their combination [six combinations]) in the $\mathbf{A}$, absence and $\mathbf{B}$, presence of thrips were determined from the internal neck tissues of onion bulbs. At each sampling period $(0,7,14,21,28,35$, and 40 days postinoculation), three onion bulbs were sampled to determine bacterial populations from the internal neck tissue and enumerated on PA-20 semi-selective medium. Data points represent the mean bacterial populations at each sampling period in two independent experiments. Bars indicate the SEM.

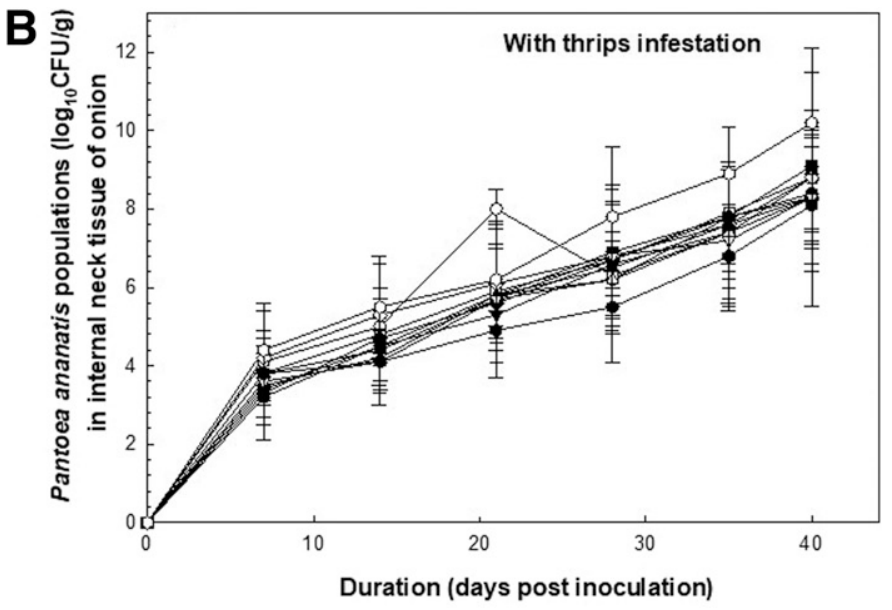


There were no significant differences when row-wise comparisons were made (PRI and PR5) for Kocide only (two rates), Actigard only (three rates), and their combinations (six different combinations) for plants either exposed to thrips or not (Table 1).

Bulb incidence of center rot. For seedlings without thrips exposure, the effect of foliar treatments on center rot bulb incidence was significant $(P=0.001)$, with $78.5 \%$ disease incidence in the nontreated control ( $P$. ananatis only). The bulb incidence values of center rot for Actigard (three rates) ranged from 65.8 to $74.6 \%$ and were not significantly different (Table 1). The bulb incidence of center rot was significantly higher for the nontreated control ( $P$. ananatis only) and the Actigard treatments (three rates) compared with Kocide (two rates) or its combination with Actigard (six different combinations). Bulb incidences were not significantly different for Kocide (two rates) or its combination with Actigard (six different combinations) and ranged from 29.2 to $39.6 \%$ (Table 1). Center rot symptoms were not observed on bulbs of the negative control.

For seedlings with thrips exposure, the effect of foliar treatments on center rot bulb incidence was not significant $(P=0.384)$; the nontreated control ( $P$. ananatis only) had a disease incidence of $90.5 \%$ (Table 1). The bulb incidence values for treatments with Actigard (three rates), Kocide (two rates), and their combination (six combinations) were not significantly different from each other or from the nontreated control ( $P$. ananatis only). The bulb incidence for the foliar treatments, including Actigard (three rates), Kocide (two rates), and their combinations (six combinations), ranged from 70.2 to $83.8 \%$ (Table 1 ).

When row-wise comparisons were made for treatments with Kocide (two rates) or in combination with Actigard (six different combinations) for the plants that were either exposed to thrips or not, bulb incidences were significantly higher for the former scenario than the latter $(P<0.05)$ (Table 1$)$. Bulb incidences of center rot for Actigard treatments under thrips exposure were significantly higher than the nonexposed scenarios. A significantly higher bulb incidence was even observed for the nontreated control ( $P$. ananatis only) under thrips exposure than the nonexposure scenario $(P<0.05)$ (Table 1$)$. Center rot symptoms were not observed for bulbs from the negative control. Overall, there was a significant interaction between thrips exposure and chemical treatment $(P=0.036)$.

Presence of $P$. ananatis in infected bulbs. Bacterial colonies isolated from symptomatic onion bulbs $(n=10)$ were tested to confirm their identity. Colonies were yellow pigmented, gram negative, positive for indole, and had their DNA amplified with real-time PCR species-specific primers. One hundred percent of the bulbs expressing symptoms were positive for $P$. ananatis. Asymptomatic bulbs were negative for colonies indicative of $P$. ananatis. Also, P. ananatis colonies were not recovered from the bulbs used as the negative control.

\section{DISCUSSION}

Previous studies identified three susceptible growth stages (first leaf senescence, bulb initiation, and bulb swelling) that led to the development of bulb symptoms; based on these observations, it was hypothesized that targeted protection during these susceptible growth stages may influence center rot bulb symptoms (Stumpf et al. 2017). Furthermore, it was also hypothesized that thrips feeding may impact the efficacy of foliar treatments. The results of

\section{Control (Pantoea ananatis 97-1)}

Actigard $(70 \mathrm{~g} / \mathrm{ha})+K o c i d e ~ 3000(2.2 \mathrm{~kg} / \mathrm{ha})$

Actigard (70 g/ha)+Kocide 3000 (1.7 kg/ha)

Actigard (52.5 g/ha)+Kocide $3000(2.2 \mathrm{~kg} / \mathrm{ha})$

Actigard $(52.5 \mathrm{~g} / \mathrm{ha})+$ Kocide $3000(1.7 \mathrm{~kg} / \mathrm{ha})$

Actigard ( $35 \mathrm{~g} / \mathrm{ha})+K o c i d e ~ 3000(2.2 \mathrm{~kg} / \mathrm{ha})$

Actigard ( $35 \mathrm{~g} / \mathrm{ha})+$ Kocide $3000(1.7 \mathrm{~kg} / \mathrm{ha})$

Kocide $3000(2.2 \mathrm{~kg} / \mathrm{ha})$

Kocide 3000 (1.7 kg/ha)

Actigard (70 g/ha)

Actigard (52.5 g/ha)

Actigard (35 g/ha)

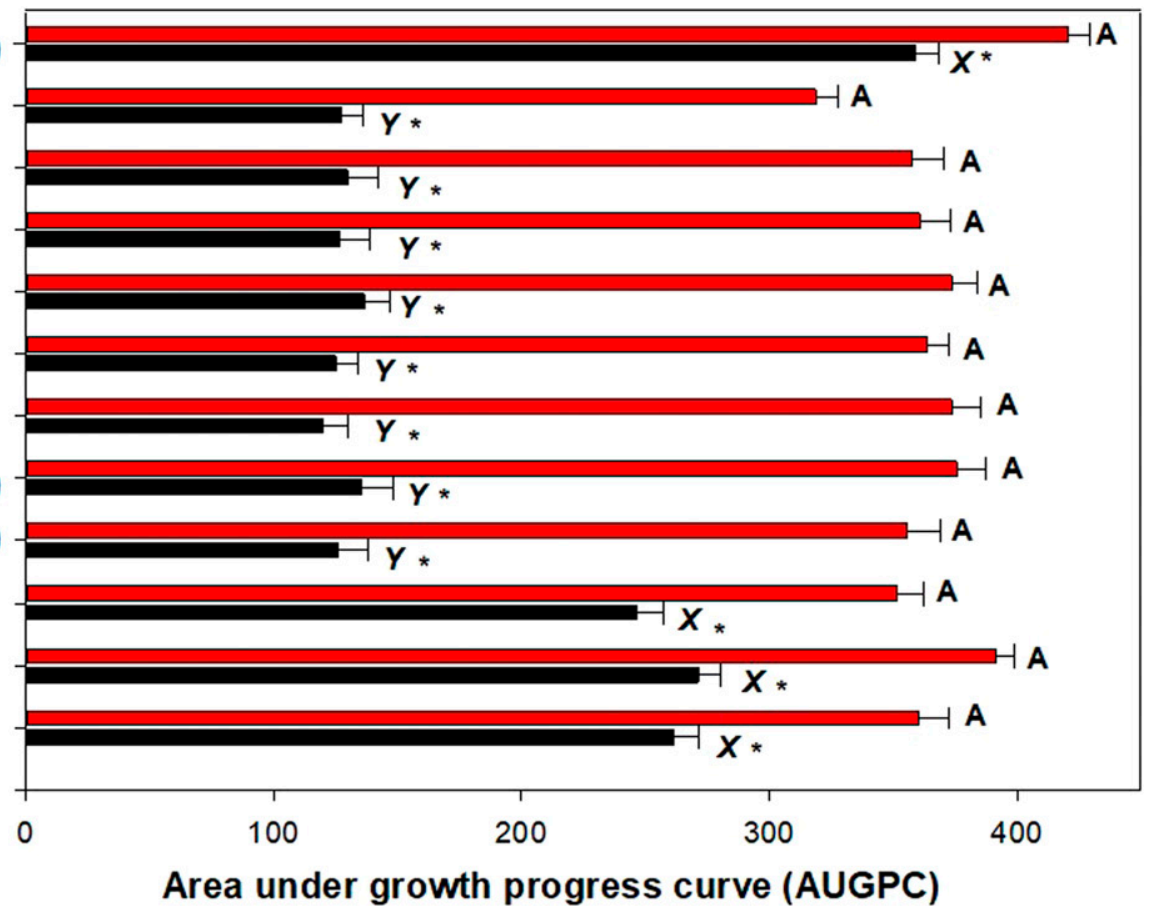

Without thrips infestation

Thrips infestation

Fig. 3. Area under the growth progress curve (AUGPC) for Pantoea ananatis in internal neck tissues of onions in response to chemical treatments (acibenzolar-Smethyl [Actigard; three rates], copper hydroxide [Kocide 3000; two rates], and their combination [six combinations]) with and without thrips exposure. The AUGPC for each replicate per treatment was calculated as follows: $\Sigma_{i=1}\left[\left(Y_{i+n 1}+Y_{i}\right)\right] / 2\left[X_{i+1}-X_{i}\right]$, where $Y_{i}$ is the bacterial population at the $i$ th observation, $X_{i}$ is the time in hours at the $i$ th observation, and $n$ is the total number of observations. Analysis of variance was conducted on AUGPC values to determine the significance of treatment effects on $P$. ananatis populations, and Fisher's least significant difference test $(P<0.05)$ was used for mean separations. In addition, the same treatments were compared under thrips exposure and without thrips exposure scenarios and analyzed with a $t$ test at $P=0.05$. 
the current study demonstrated that center rot bulb incidence at either growth stage (bulb initiation and bulb swelling) was reduced under conditions in which onion seedlings were not exposed to thrips but were protected with foliar chemical treatments such as Kocide (1.7 kg/ha), Actigard (35 g/ha), or Kocide (1.7 kg/ha) plus Actigard (35 g/ha). Among the treatments, Kocide performed significantly better than the Actigard-only treatment when applied at either of the two growth stages. Application of Kocide plus Actigard significantly reduced bulb incidence compared with Actigard alone, indicating that most of the control was attributable to Kocide rather than Actigard. It is also important to note that the strain used (PNA 97-1) was reconfirmed to be copper sensitive prior to the greenhouse studies.

When thrips were present on onion plants, the percentage of onion bulbs with center rot was not significantly different regardless of whether plants were treated with Actigard, Kocide, or both (Fig. 1B). Thrips are important in spreading bacteria between onion plants; therefore, center rot incidence in the nontreated control should have been higher when thrips were exposed versus when they were not. However, this was not evident in this study. These observations can partly be explained by the overwhelming effect of thrips despite chemical (Kocide or Actigard) treatments, as they can carry $P$. ananatis and transmit the pathogen to onion plants. Another aspect to consider is that the chemicals used in this study do not affect thrips; hence, bacterial transmission via thrips and associated bulb rot were not significantly different across treatments and the nontreated control. Also, it is possible that the plant defense mechanism might have been overwhelmed when the onion plants were exposed to thrips and, irrespective of the chemical treatments, bulb rot incidence was not reduced for chemically treated versus nontreated plants.

The targeted timing of chemical application at bulb initiation or bulb swelling was not significantly different. Hence, we concentrated on bulb initiation stage-based protection and evaluated different rates of Kocide (two rates: 1.7 and $2.2 \mathrm{~kg} / \mathrm{ha}$ ) or Actigard (three rates: $35,52.5$, and $70 \mathrm{~g} / \mathrm{ha}$ ) or their combinations (six combinations) on various aspects of $P$. ananatis colonization in onion tissue as well as the bacterial presence or absence internally within the thrips. The aspects that were evaluated included population of $P$. ananatis colonization in neck tissue, percentage of thrips that carried internal $P$. ananatis populations in the neck region, expression of $P R 1$ and $P R 5$ in onion tissues $(72 \mathrm{~h}$ after $P$. ananatis inoculation), and ultimately the percentage of center rotinfected bulbs. Under the scenario where the onions were not exposed to thrips, foliar protection with Actigard at three different rates did not significantly influence the growth of $P$. ananatis in internal neck tissue, as the bacterial population was similar to that of the nontreated control ( $P$. ananatis only). In both Actigard-only treatments (three rates) and the nontreated control $(P$. ananatis only), $P$. ananatis populations were detected in the onion neck tissue within $7 \mathrm{dpi}$. In contrast, bacterial populations were not detected in the onion neck tissues until $21 \mathrm{dpi}$ for seedlings that were protected with either Kocide (two rates) or their combinations with Actigard (six combinations). Interestingly, the final populations of $P$. ananatis at 40 dpi with Kocide only (two rates) or their combinations with Actigard (six combinations) were at least four to five orders of magnitude less than what was observed for the Actigard-only treatments (three rates) and the nontreated control ( $P$. ananatis only). This was also evident with significantly higher AUGPC values for the Actigard-only treatments (three rates) and the nontreated control (P. ananatis only) compared with Kocide-only treatments (two rates) or their combinations with Actigard (six combinations). These observations indicate that Kocide was effective in reducing foliar $P$. ananatis populations compared with Actigard and thereby reducing bacterial populations in onion neck tissues. Since onion neck tissues are a major conduit to bulb infection for foliar $P$. ananatis, it is imperative that a chemical foliar treatment reduces the bacterial populations in foliage and thereby limits bacterial ingress or colonization in the neck tissue. Reduced bacterial populations in neck tissues may influence bulb infection and further deterioration in storage. We also surmise that the effectiveness of Kocide and Actigard combination treatments was mainly driven by Kocide, as Actigard-only treatments were not significantly different from the $P$. ananatis-only control.

Under the scenario where onions were exposed to thrips, $P$. ananatis populations in internal neck tissue were detected as early as $7 \mathrm{dpi}$ from both chemically treated onion seedlings and the nontreated control ( $P$. ananatis only). Bacterial populations in chemically protected plants and the nontreated control ( $P$. ananatis only) reached a level of approximately $10^{9}$ to $10^{10} \mathrm{CFU} / \mathrm{g}$ by $40 \mathrm{dpi}$ in internal neck tissues. In addition, AUGPC values for the treated plants and the nontreated control (P. ananatis only) were not significantly different from each other. When AUGPC values were compared between each chemical treatment and the nontreated control ( $P$. ananatis only) under thrips or nonthrips exposure scenarios, significantly higher values were observed in the former scenario than in the latter. When final bacterial populations in internal neck tissues for the chemically treated plants and the nontreated control (P. ananatis only) were compared between thrips and nonthrips exposure scenarios, $P$. ananatis populations were at least two to three orders of magnitude higher in the scenario with thrips. Interestingly, the chemical treatments (Kocide only [two rates] or their combinations [six combinations]) that significantly reduced bacterial populations in neck tissues $\left(1 \times 10^{4} \mathrm{CFU} / \mathrm{g}\right)$, compared with the nontreated control (P. ananatis only; $1 \times 10^{8}$ $\mathrm{CFU} / \mathrm{g})$ or Actigard-only treatments $\left(1 \times 10^{8} \mathrm{CFU} / \mathrm{g}\right)$, were ineffective in reducing $P$. ananatis populations compared with the nontreated control in the presence of thrips. These observations indicate that thrips exposure and feeding can overcome the efficacy of chemical treatment with Kocide, Actigard, or their combinations. The feeding wounds can open avenues for $P$. ananatis to gain ingress and colonize internal onion foliar tissues then gradually move downward toward neck tissues. The colonization of internal neck tissues with higher bacterial populations increases the risk of bacterial ingress, colonization, and ultimately rotting of onion bulbs.

Chemical treatments (Kocide, Actigard, or their combinations) did not affect the percentage of internal $P$. ananatis-positive thrips, which were sampled from the neck tissue. It is possible that after chemical treatment followed by a P. ananatis challenge inoculation, thigmotactic thrips might carry superficial bacterial populations to the internal neck tissues. Internal neck tissues are often favored by thrips for colonization where feeding-mediated damage and subsequent bacterial infection might occur. Effective chemical treatment (Kocide) may reduce superficial foliar bacterial populations; however, thrips infestations may reduce treatment efficacy by inducing feeding-related injuries in foliar tissues and also by migrating to the internal tissue regions where chemical protection is difficult to achieve. It was also observed that despite chemical treatments, thrips were able to carry $P$. ananatis to the internal neck region within $7 \mathrm{dpi}$ and $100 \%$ of the thrips were positive for internal bacterial populations by $21 \mathrm{dpi}$. Aggressive thrips colonization and bacterial transmission in neck tissues increases the risk of bulb rot incidence.

Actigard is a well-known plant defense inducer that induces host defense through induction of key genes (PRI and PR5) in the SAR pathway against biotrophic pathogens (Glazebrook 2005). Chemical treatment with Actigard only (three rates) or its combination with Kocide (six combinations) significantly induced expression of $P R 1$ and PR5 in foliar tissues ( $72 \mathrm{~h}$ after $P$. ananatis inoculation) compared with Kocide only (two rates) or the nontreated control ( $P$. ananatis only). Irrespective of thrips exposure, significant differences in expression levels of $P R I$ and $P R 5$ were not observed for the same group of chemical treatment. These observations indicate that thrips exposure did not influence these key SAR pathway genes, which is not surprising because $P$. ananatis most 
likely behaves as a hemibiotroph. Based on controlled greenhouse experiments, it was observed that $P$. ananatis could increase to high populations in both live and necrotic onion leaf tissues. In addition, insect herbivory, including thrips feeding, can induce jasmonic acid (JA) pathway events in plants and a JA inducer would potentially be a better alternative than a SAR inducer in the center rot pathosystem (Rahman et al. 2012). Future greenhouse and field studies will evaluate these questions.

Thrips exposure influenced bulb rot incidence. Irrespective of the rates of Kocide, Actigard, or their combinations, center rot incidence was not significantly different for any of the chemical treatments that were exposed to thrips. In fact, bulb incidences were significantly higher for the same treatments that were exposed to thrips compared with those that were not. These observations indicate that the $P$. ananatis population in neck tissue can reach high levels and colonization of thrips in these tissues most likely plays an important role.

Thrips may carry these bacteria externally or internally from foliar tissues to the tight whorl of onion foliage (at the neck) where they prefer to colonize (Palomo et al. 2015). Feeding and defecating in neck regions can result in bacterial transmission and ingress and in further movement and colonization of internal bulb tissues. We acknowledge that mere expression of the SAR pathway genes by Actigard application is not effective in reducing $P$. ananatis population in neck tissues or center rot incidence in the bulb. Grode et al. (2017) made similar observations with increased symptom expression in onion foliage caused by thrips feeding. The authors observed that onion seedlings infested with thrips and inoculated with $P$. ananatis had more necrotic tissue compared with nonexposed onion seedlings. In addition, Grode et al. (2017) also demonstrated that symptom severity increased with an increase in thrips density, and thrips feeding facilitated center rot development by providing entry sites for the bacterium into leaf tissue. A field study demonstrated that when a bactericide spray program was used in conjunction with a thrips management program, a significant reduction in center rot incidence in bulbs was observed compared with when the same bactericide spray was used without a thrips management program (Dutta et al. 2020). These observations reiterate that thrips management is critical in managing center rot in onion.

Overall, it was observed that chemical protection with Kocide during the bulb initiation and bulb swelling stages was effective in reducing center rot incidence in onion bulbs in the absence of thrips. In contrast, similar levels of growth stage-based protection at either the bulb initiation or bulb swelling stages were not observed in the presence of thrips. Actigard displayed limited efficacy, whereas Kocide showed a higher level of efficacy in reducing center rot symptoms in bulbs when applied at the bulb initiation or bulb swelling stage. Furthermore, bulb initiation stage-based protection with different rates of Kocide, Actigard, or their combinations affected various aspects of the $P$. ananatis bulb infection process in the absence of thrips. In contrast, such differences in the bulb infection process or treatment efficacy were not observed in the presence of thrips, as feeding-induced damage can reduce the efficacy of protective chemical treatments against $P$. ananatis. Hence, it is critical to implement an effective management strategy including protective chemical treatments against $P$. ananatis, thrips management using cultural and chemical tactics, and weed management at both growth stages. Grode et al. (2019) demonstrated the benefit of using an effective thrips management program in reducing bacterial stalk rot and leaf necrosis (causal agent: $P$. agglomerans) in onion under field conditions in Michigan. The authors demonstrated that chemical treatments targeting $P$. agglomerans (NuCop 50, Kasugamycin, or Kocide 3000) used along with a thrips management program significantly reduced disease severity compared with when chemical treatments were used alone. Although protective treatments were ineffective when thrips were present, they could provide some level of protection against bacterial dissemination through rain splash dispersal and other passive modes of pathogen spread onto foliage. However, it is important to understand the biology of thrips-onion-P. ananatis infections, including the modes by which thrips bypass foliar chemical protectants. It should be noted that only a single application of these chemical compounds was made in this study, which is not an usual use pattern in the field. Further studies with multiple applications of these chemical compounds should be evaluated under various thrips exposure regimes that may reflect to some extent the conditions a grower may encounter in the field. Developing an improved integrated management program that emphasizes growth stage-targeted protective chemical treatments for $P$. ananatis and rigorous vector management can reduce the frequency of chemical application (copper-based bactericides) and thus minimize input cost. Further studies are designed to explore different bactericide- and insecticide-based programs for the effective integrated disease management against $P$. ananatis.

\section{ACKNOWLEDGMENTS}

We thank Matthew Tyler Garrick, Medora Hoopes, Walt Sanders, and David Abgott for technical assistance in the field and laboratory.

\section{LITERATURE CITED}

Babu, R. M., Sajeena, A., Samundeeswari, A. V., Sreedhar, A., Vidhyasekeran, P., and Reddy, M. S. 2003. Induction of bacterial blight (Xanthomonas oryzae pv. oryzae) resistance in rice by treatment with acibenzolar-Smethyl. Ann. Appl. Biol. 143:333-340.

Boyhan, G. E., Torrance, R. E., Riner, C. R., Cook, J. E., Dollar, M. A., Curry, S. D., Hill, C. R., Thigpen, D. R., and Bateman, A. G. 2014. Five-year evaluation of short-day onion varieties. Int. J. Veg. Sci. 20:150-184.

Brady, C. L., Goszczynska, T., Venter, S. N., Cleenwerck, I., De Vos, P., Gitaitis, R. D., and Coutinho, T. A. 2011. Pantoea allii sp. nov., isolated from onion plants and seed. Int. J. Syst. Evol. Microbiol. 61:932-937.

Carr, E. A., Zaid, A. M., Bonasera, J. M., Lorbeer, J. W., and Beer, S. V. 2013. Infection of onion leaves by Pantoea ananatis leads to bulb infection. Plant Dis. 97:1524-1528.

Cole, D. L. 1999. The efficacy of acibenzolar-S-methyl, an inducer of systemic acquired resistance, against bacterial and fungal diseases of tobacco. Crop Prot. 18:267-273.

Dutta, B., Anderson, F., Smith, S., and Gitaitis, R. 2017. Epiphytic survival of Pantoea ananatis on Richardia scabra L. in Georgia. Plant Dis. 101:613-618.

Dutta, B., Barman, A. K., Srinivasan, R., Avci, U., Ullman, D. E., Langston, D. B., and Gitaitis, R. D. 2014. Transmission of Pantoea ananatis and P. agglomerans, causal agents of center rot of onion (Allium cepa), by onion thrips (Thrips tabaci) through feces. Phytopathology 104:812-819.

Dutta, B., Gitaitis, R., Barman, A., Avci, U., Marasigan, K., and Srinivasan, R. 2016. Interactions between Frankliniella fusca and Pantoea ananatis in the center rot epidemic of onion (Allium cepa). Phytopathology 106:956-962.

Dutta, B., Tyson, C., Edenfield, J., Williams, Z., Tanner, S., Shirley, A., Reeves, B., and Powell, S. 2020. Evaluation of onion growth stage directed chemical applications and thrips management program on center rot incidence in onion bulbs in Georgia, 2019. Plant Dis. Manage. Rep. 14:V091.

Edens, D. G., Gitaitis, R. D., Sanders, F. H., and Nischwitz, C. 2006. First report of Pantoea agglomerans causing a leaf blight and bulb rot of onions in Georgia. Plant Dis. 90:1551.

ElMorsi, A., Abdelkhalek, A., AlShehaby, O., and Hafiz, E. E. 2015. Pathogenesis-related genes as tools for discovering the response of onion defense system against Iris yellow spot virus infection. Botany 93:735-744.

Gent, D. H., and Schwartz, H. F. 2005. Management of Xanthomonas leaf blight of onion with a plant activator, biological control agents, and copper bactericides. Plant Dis. 89:631-639.

Gitaitis, R., Walcott, R., Culpepper, S., Sanders, H., Zolobowska, L., and Langston, D. 2002. Recovery of Pantoea ananatis, causal agent of center rot of onion, from weeds and crops in Georgia, USA. Crop Prot. 21:983-989.

Gitaitis, R. D. 2014. Finding center rot and IYSV. Onion World 30:20-23.

Gitaitis, R. D., and Gay, J. D. 1997. First report of a leaf blight, seed stalk rot, and bulb decay of onion by Pantoea ananas in Georgia. Plant Dis. 81:1096.

Gitaitis, R. D., Walcott, R. R., Sanders, H. F., Zolobowska, L., and Diaz-Perez, J. C. 2004. Effects of mulch and irrigation system on sweet onion: II. The epidemiology of center rot. J. Am. Soc. Hortic. Sci. 129:225-230.

Gitaitis, R. D., Walcott, R. R., Wells, M. L., Diaz Perez, J. C., and Sanders, F. H. 2003. Transmission of Pantoea ananatis, causal agent of center rot of onion, by tobacco thrips, Frankliniella fusca. Plant Dis. 87:675-678. 
Glazebrook, J. 2005. Contrasting mechanisms of defense against biotrophic and necrotrophic pathogens. Annu. Rev. Phytopathol. 43:205-227.

Goszczynska, T., Moloto, V. M., Venter, S. N., and Coutinho, T. A. 2006. Isolation and identification of Pantoea ananatis from onion seed in South Africa. Seed Sci. Technol. 34:655-668.

Grode, A., Chen, S., Walker, E. D., and Szendrei, Z. 2017. Onion thrips (Thysanoptera: Thripidae) feeding promotes infection by Pantoea ananatis in onion. J. Econ. Entomol. 110:2301-2307.

Grode, A. S., Brisco-McCann, E., Wiriyajitsonboom, P., Hausbeck, M. K., and Szendrei, Z. 2019. Managing onion thrips can limit bacterial stalk and leaf necrosis in Michigan onion fields. Plant Dis. 103:938-943.

Livak, K. J., and Schmittgen, T. D. 2001. Analysis of relative gene expression data using realtime quantitative PCR and the $2^{-\Delta \Delta C t}$ method. Methods 25:402-408.

Munger, F. 1942. A method of rearing citrus thrips in the laboratory. J. Econ. Entomol. 35:373-375.

Nischwitz, C., Gitaitis, R., Sanders, H., Langston, D., Mullinix, B., Torrance, R., Boyhan, G., and Zolobowska, L. 2007. Use of fatty acid methyl ester profiles to compare copper-tolerant and copper-sensitive strains of Pantoea ananatis. Phytopathology 97:1298-1304.

Orloff, S., Natwick, E. T., Godfrey, L. D., and Dara, S. K. 2016. Thrips. Page 9 in: UC IPM pest management guidelines-onion/garlic. UC ANR Publication 3453. University of California Integrated Pest Management, Davis, CA.
Palomo, L. T., Martinez, N. B., Johansen-Naime, R., Napoles, J. R., Leon, O. S., Arroyo, H. S., and Graziano, J. V. 2015. Population fluctuations of thrips (Thysanoptera) and their relationship to the phenology of vegetable crops in the central region of Mexico. Fla. Entomol. 98:430-438.

Rahman, T. A. E., Oirdi, M. E., Gonzalez-Lamothe, R., and Bouarab, K. 2012. Necrotrophic pathogens use the salicylic acid signaling pathway to promote disease development in tomato. Mol. Plant-Microbe Interact. 25: 1584-1593.

Riley, D. G., Sparks, A. N., and Chitturi, A. 2014. Current status of thrips (Thysanoptera: Thripidae) in Vidalia onions in Georgia. Fla. Entomol. 97: 355-361.

Schmittgen, T. D., and Livak, K. J. 2008. Analyzing real-time PCR data by the comparative CT method. Nat. Protoc. 3:1101-1108.

Stumpf, S., Gitaitis, R., Coolong, T., Riner, C., and Dutta, B. 2017. Interaction of onion cultivar and growth stages on incidence of Pantoea ananatis bulb infection. Plant Dis. 101:1616-1620.

Stumpf, S., Kvitko, B., Gitaitis, R., and Dutta, B. 2018. Isolation and characterization of novel Pantoea stewartii subsp. indologenes strains exhibiting center rot in onion. Plant Dis. 102:727-733.

Walcott, R. R., Gitaitis, R. D., Castro, A. C., Sanders, F. H., Jr., and Diaz-Perez, J. C. 2002. Natural infestation of onion seed by Pantoea ananatis, causal agent of center rot. Plant Dis. 86:106-111. 